\title{
ENVIRONMENTAL RESPONSIBILITY- AN ESSENTIAL COMPONENT OF SOCIAL RESPONSIBILITY FOR THE MOST IMPORTANT ROMANIAN COMPANIES
}

\author{
Valentina-Mariana Mănoiu ${ }^{1 *}$ and Alexandru Valeriu Gâdiuţă \\ ${ }^{1}$ Assoc. Prof. Dr., University of Bucharest, Faculty of Geography, ROMANIA, \\ valentina.mariana.manoiu@gmail.com \\ ²Councillor, General Council of Bucharest, ROMANIA, alexandru.gadiuta@gmail.com \\ ${ }^{*}$ Corresponding author
}

\begin{abstract}
The environmental impact is one of the most important consequences of a company's economic activity. By their operations, economic entities constantly strain the environment. Because of this significant effect, the environmental component of corporate social responsibility (CSR) is very important. The present study is a historical descriptive-analytic investigation of social responsibility and its environmental component in the case of Romanian companies. The aim of the research is to create a historical analysis of this concept and its environmental aspects at the national level, and also to present the way in which some of the most important Romanian companies have built up the environmental component of their corporate social responsibility policies, as well as the projects that have been undertaken in this area. The selection of the companies was based on their size, as we sought to present major companies that have a high degree of involvement in this field. For each and every company, we analyzed the components of the environmental social responsibility that are created in order to reduce environmental impacts as well as any projects aimed at increasing the general public's involvement in protecting nature. In Romania, the concept of corporate social responsibility did not develop as quickly as it did at an international level. The main cause was the different political regime of Romania compared to the situation found in the countries where CSR emerged. This political situation also led to economic, social and environmental differences. In Romania, after the regime change that occurred in 1989, a period of economic and social opening towards international trends and currents ensued. As social and economic ties with the outside world intensified, the concept of a company's social responsibility appeared in Romania as well. The field of social responsibility in Romania experienced a constant growth over the last years, but this evolution occurred, for the most part, through a series of individual projects (belonging to companies, NGOs and researchers), without a general and unitary view and without a strong cooperation between those involved. An important step for CSR took place in 2015, with the creation of the Global Compact Network Romania, a part of the Global Compact Network under the aegis of the United Nations, the largest social responsibility project to date. Until now, 27 participants have joined the national Global Compact network, including some of the most important companies in Romania. The environmental component of corporate social responsibility policies for Romanian companies is structured in
\end{abstract}


two parts. The first one is concerned with internal policies and actions aimed at reducing the environmental impact of the company's activities. The second aspect consists of policies regarding the company's interactions with the external environment and the community where it operates, trying to support its development.

Keywords: corporate social responsibility, environmental responsibility, Romania, companies, projects

\section{PURPOSE OF THE STUDY AND BACKGROUND}

The present study is a historical descriptive-analytic investigation of social responsibility and its environmental component in the case of Romanian companies. The aim of the research is to create a historical analysis of this concept and its environmental aspects at the national level, and also to present the way in which some of the most important Romanian companies have built up the environmental component of their corporate social responsibility policies, as well as the projects that have been undertaken in this area. The selection of the companies was based on their size, as we sought to present major companies that have a high degree of involvement in this field. For each and every company, we analyzed the components of the environmental social responsibility that are created in order to reduce environmental impacts as well as any projects aimed at increasing the general public's involvement in protecting nature.

The concept of corporate social responsibility does not have a well-established definition. It is a complex notion, whose content varies depending on the angle from which it is analyzed and the manner in which researchers approach it (Mănoiu and Gâdiuţă, 2016, p. 632).

By looking in the Dictionary of the Romanian Language (Dictionary of the Romanian Language, 1998), we found that Responsibility is an obligation to do something, to answer in front of someone, to be held accountable, to accept and to suffer the consequences. It is a duty, a function, something for which a person is responsible - It comes from the French word responsabilité (Mănoiu and Gâdiuţă, 2016, p. 632).

Social is an adjective that characterizes something that is related to society, which is specific to society and is connected to the existence of people in a society. This word also comes from French (social) and has its origins in Latin (socialis) (Mănoiu and Gâdiuţă, 2016, p. 632).

Starting from this semantic analysis of the two words, we have tried to create a preliminary definition of CSR (Mănoiu and Gâdiuţă, 2016, p. 632) by joining the two explanations:

\section{Social responsibility means responsibility/accountability towards society.}

A general definition of the concept of social responsibility offered by the Cambridge Business English Dictionary (2011) reads as follows: Social responsibility is the practice of producing goods and services in a way that is not harmful to society or the environment (Mănoiu and Gâdiuţă, 2016, p. 632).

\section{CORPORATE SOCIAL RESPONSIBILITY IN ROMANIA}

In Romania, the concept of corporate social responsibility did not develop as quickly as it did at an international level. The main cause is the different political regime of Romania compared to the situation found in the countries where this concept emerged. This situation also led to economic, social and environmental differences.

At the time when, internationally, the concept of corporate social responsibility appeared and was theorized, Romania was living under a communist regime. This involved a centralized economy, which was planned and controlled by the state. The environment and its accompanying issues were often ignored and neglected in Romania at that time, as the main goal was to maximize economic results while disregarding the environmental impact of such actions. Among the most significant actions that harmed the environment were the strong industrialization process, intensive agricultural practices, large-scale exploitation of natural resources and forced urbanization. All these policies, that were implemented without due attention to their impact on nature, led to severe environmental degradation.

After the regime change that occurred in 1989, Romania began its transition towards a market economy, which coincided with a period of social and economic opening of our country towards western states and international organizations. Soon, Romania established EU accession as its main goal, and, in order to achieve it, embarked on a process of amending and harmonizing its legislation and of meeting certain economic and social objectives. 
In the field of corporate social responsibility, a concept that was not born in Romania, these transformations represented the premises for the local establishment and development of the concept. The fact that this notion comes from outside is reflected in the name it has taken in Romania, where people talk about CSR the English acronym for Corporate Social Responsibility.

In Romania, this concept first emerged in the NGO environment, which tried by means of various types of actions to promote it. CSR truly began to take root in Romania when multinational companies began to increase both in number and in overall strength. These companies came from abroad with an organizational culture that had already included the concept of CSR and, as they began to develop local branches, foreign businesses also started to implement CSR policies locally.

At first, major companies sponsored a host of projects and charitable actions. During this phase, we cannot speak of an assumed policy of implementing CSR, but rather about an opening of these companies to a number of social projects.

In 2004, the first CSR report was published, which analyzes exclusively the activity of a Romanian company, the "Orange Romania 2003 Social Responsibility Report" (Orange Romania 2003 SR Report). It studied the policies of Orange towards social responsibility and its activities in this area in the year before its publication. The importance of the said report lies in its innovative character on the local market, where, for the first time, a company presented an explicit policy in the field of social responsibility.

The next report belonged to cement manufacturer Holcim, and it appeared in 2005 (Holcim Romania 2005 Sustainable Development Report). We should note that this is the first sustainability report of a Romanian company involved in a highly polluting industry, and it represented a premiere, serving as a model of openness and transparency.

By analyzing the reports issued by Romanian companies on their social responsibility policies, it is important to look for the following elements: the year when the report was created, the methodology behind it - for example the use of a standardized international model and the verification and certification of the way in which it was drafted by international companies.

In 2006, Orange published the first Romanian social responsibility report (Orange Romania 2006 CSR Report) that was audited by an international company (in this case, the business consultancy and audit firm Ernst\&Young). This auditing represents a mark of trust for the telecommunications company and it raised the public's confidence in the reports issued by companies. In 2008, again for the first time, Romania is included in an international study on social responsibility and the reporting carried out by companies in this field. The study was performed by the KPMG business consultancy and audit firm, and it mentions the 24 Romanian companies that had published CSR reports. In 2010, the CSR report of OTP Bank was the first one in Romania to use in its methodology the G.R.I. Reporting Guide (Global Reporting Initiative), seen at that time as one of the most important social reporting methods internationally. In 2011, Cosmote Romania issues the first CSR report that is reviewed by G.R.I. This evolution continues, and, in 2013, the first CSR report using the G.R.I. 4 standard, the highest one available, is published, belonging to GSK Romania (GSK Romania 2013 Corporate Responsibility Report). Romradiatoare Brașov is the first locally owned company that issues a CSR report, in 2012.

It is thus obvious that there is a constant increase in the number of companies that undertake social responsibility policies and publish annual activity reports. A study of KPMG shows that, in 2011, 54 companies released CSR reports, while in 2013, 69 companies published such documents (KPMG 2013 Survey of Corporate Responsibility Reporting).

Starting from January $1^{\text {st }} 2017$, EU Directive no. 2014/95/EU imposes an obligation on companies with more than 500 employees to create and release an impact report, and this legal act will also apply to Romania. This shall represent a turning point for CSR in Romania, as it will bring about an unprecedented amount of data on local companies. It is expected that this increased transparency will spur the involvement of companies and increase competition in the area of social responsibility. At least 727 Romanian companies with more than 500 employees will be obliged to publish such activity reports, according to CSR Agency, a consulting firm in the fields of sustainability and social responsibility in Romania (CSR Report website, 2015; CSR Agency website, 2016).

The development of social responsibility in Romania manifested itself through the expansion of available information sources on this subject. In 2005, the first Romanian language book on the topic of CSR was published, aptly named "Corporate Social Responsibility", and written by Luminița Oprea (Oprea, 2005). In 2006, the first on-line portal with CSR information and resources was launched, www.responsabilitatesocială.ro (Social Responsibility website), a public source of knowledge dedicated to 
spreading awareness on the principles of social responsibility. The portal was created by the Selenis Agency, in partnership with JTI Romania. All these actions show a complex development of the concept of social responsibility in Romania.

The field of social responsibility in Romania experienced a constant growth over the last years, but this evolution occurred, for the most part, through a series of individual projects (belonging to companies, NGOs and researchers), without a general and unitary view and without a strong cooperation between those involved. An important step for CSR took place in 2015, with the creation of the Global Compact Network Romania, a part of the Global Compact Network under the aegis of the United Nations, the largest social responsibility project to date. The local office was established through a mandate given by the UN to a Romanian organization, "The CSR Agency", on April $17^{\text {th }} 2014$ (CSR Agency website). This company was involved in implementing the project. The official launch of the Global Compact Network Romania happened on May $15^{\text {th }} 2015$ (Global Compact Network Romania website). Until now, 27 participants have joined the national Global Compact network. According to their fields of activity, they are:

- The academic environment: The National Economic Research Institute "Costin C. Kirițescu"; Association Maastricht School of Management Bucharest.

- NGOs: MaiMultVerde, Salvați Copiii România, the Mereu Aproape Foundation, Asociația De-a arhitectura, the Gala Societății Civile Foundation, The Romanian Association for International Road Transport (ARTRI).

- Companies (according to their size):

- Major companies: Alro S.A. (Vimetco), Băneasa Developments, Coca-Cola HBC România, Continental Anvelope Timișoara, Enel Romania, KMG International (Rompetrol), OMV Petrom, Pirelli Tyres Romania, Raiffeisen Bank Romania, Telekom Romania, Unilever South Central Europe;

- Medium sized companies: EY Romania, INSOFT Development \& Consulting, Mercedes-Benz Romania;

- Micro-enterprises: Lutz \& Associates, The CSR Agency; - small companies: Advanced Technologies (Vonino), Carbon Solutions Global Romania.

The local Global Compact network will be active on two fronts: on the one hand, it will promote the concept of social responsibility at national level and, on the other, it will implement an activity program for the network's members, wishing to maximize their involvement in the UN Global Compact. Global Compact Network Romania promotes the ten principles of the Global Compact, covering human rights, labor, the environment and the fight against corruption, and supports its members by using its resources (Global Compact Network Romania website), creating guidelines for communicating the progress achieved, holding regular events for sharing best practices, organizing working groups and maintaining relations with other similar networks.

\section{ENVIRONMENTAL RESPONSIBILITY - AN ESSENTIAL COMPONENT OF SOCIAL RESPONSIBILITY FOR THE MOST IMPORTANT ROMANIAN COMPANIES}

The environmental impact is one of the most important consequences of a company's economic activity. Through their operations, economic entities constantly strain the environment. This significant effect gives the importance of the environmental component of CSR.

In this section of our paper, we shall present the manner in which some of the most important companies in Romania have built their environmental aspects of CSR as well as the specific projects that they have implemented. The selection of the companies was based on their size, as we sought to present major companies that have a high degree of involvement in this field. For each and every company, we analyzed the components of the environmental social responsibility that are created in order to reduce environmental impacts as well as any projects aimed at increasing the general public's involvement in protecting nature.

\subsection{OMV Petrom}

OMV Petrom is the largest integrated oil producing company in South-Eastern Europe, active in the fields of exploration and production, oil refining, the petrochemical industry, marketing, the production of natural gases and energy generation (OMV Petrom website). By its nature and scale, the activities of OMV Petrom have a major impact on the environment. 
OMV Petrom is one of the most active promoters of CSR in Romania. It is the first local company to adopt the principles and join the UN Global Compact Program. The first sustainability report was released in 2012 and describes the company's activity in 2011. Other reports followed, presenting the activities carried out in 2012, 2013 and 2014 (OMV Petrom 2011-2014 Sustainability Reports). The 2013 report is the most recent one targeting OMV's national activities, as the 2014 report deals with the group's international actions.

OMV Petrom's policy is based on its own concept: "Resourcefulness". It was launched in 2011 and puts sustainability at the heart of every activity performed. In the 2013 report, the concept is presented as "our approach to implement initiatives in areas such as environmental management, new energy sources, education and development, health, security, diversity, business ethics, human rights, the involvement of stakeholders and local communities in a single, holistic strategy." (OMV Petrom 2013 Sustainability Report).

The environmental social responsibility component of OMV Petrom is based on three principles:

\section{Eco-efficiency}

By this concept, the company tries to institute the best existing practices in the field of environmental management, focusing on carbon emissions, water management and energy efficiency. Energy efficiency is seen as the greatest opportunity to reduce the impact of economic activities on the environment. As the company develops, it uses up more energy, which, in turn, makes energy efficiency even more important for future growth.

In 2013 , the target set by OMV Petrom was to reduce the carbon intensity of its assets by $2 \%$ compared to 2012. This goal was in fact exceeded, as the company managed to reduce the above mentioned parameter by $3.4 \%$. In 2013, the ISO 50001 certification was awarded in the areas of supply, marketing and trade for OMV Petrom SA and for all of the activities of OMV Petrom Gas SRL (OMV Petrom website). This means that the energy, performance monitoring and efficiency improving goals of the company have been met.

Also in 2013 , efforts have been made to improve water use efficiency, by investing in cutting edge water treatment stations and by modernizing the waste water treatment station of the Petrobrazi Refinery. These actions led to an $8 \%$ reduction in water consumption compared with 2012, the equivalent of 24.2 million $^{3}$. The same year, 11.29 million $\mathrm{m}^{3}$ of waste water have been treated in an adequate manner. The exploration and production activities of OMV Petrom manage significant amounts of water which is a byproduct of petroleum and gas extraction, amounting to 36.4 million $\mathrm{m}^{3}$ in 2013 . More than $96 \%$ of all resulting water was injected back in the oil and gas deposits after undergoing a treatment process. The rest is purified and evacuated in surface water courses, with due respect for existing environmental regulations (OMV Petrom website).

In 2013, all operational locations of OMV Petrom were included in the company's waste prevention and reduction plans. Audits were performed with regards to waste management and actions aimed at improving the performance at all levels were planned. The total amount of waste generated in 2013 was reduced by $20 \%$ compared to 2012 . This is due mostly to a decline in the number of demolitions and the completion of the bio-rehabilitation of the silt settling tanks at the Arpechim Refinery. More than $50 \%$ of all waste generated by OMV Petrom was recycled (OMV Petrom website).

\section{Eco-innovation}

This aspect refers to research activities that seek to find and apply new technologies which have a minimal environmental impact. In addition, research is performed in the field of alternative energy sources which, in time, could come to replace traditional fossil fuels.

\section{Education for Development}

OMV Petrom encourages and promotes educational projects that develop skills. This is true not only for its employees but also for stakeholders. In the communities where the company operates, it supports educational projects on the subjects of environmental protection, energy and entrepreneurship. For its employees, OMV Petrom offers continuous training programs and internal communication courses that help spread the best available practices in environmental management. In 2013, courses focused on water resources management.

Another important aspect of OMV Petrom's environmental social responsibility policy is the prevention of environmental accidents. A wide range of activities are organized in order to reduce and prevent the impact of hydrocarbon leaks. A map of hydrocarbon leak risk has been created, offering detailed information on the hazards and possible effects of leaks at specific points along the company's pipelines. $60 \%$ of OMV Petrom's assets are included on maps of leak risks. These maps illustrate all pipelines and indicate "critical points", with a high risk of leaks. The data is used to apply preventive action plans and prepare effective reaction 
measures in case of a spill. In 2013, 4.400 pipelines have been evaluated for their risks, along with 12.000 static pieces of equipment. 600 installations have been classified according to their risk, such as compression stations and storage tanks (OMV Petrom website).

Another policy undertaken by the OMV Petrom Group is the effort to create and distribute products that have the least possible impact on the environment: gas and diesel fuel from the Petrobrazi Refinery do not contain sulfur (a sulfur content of less than $10 \mathrm{ppm}$ ). Furthermore, the company produces compressed natural gas (CNG), which, when used, decreases $\mathrm{CO}_{2}$ emissions by $20 \%$ and carbon monoxide emissions by $80 \%$, while having virtually no particle emissions. It is available in 236 out of 785 gas stations belonging to OMV Petrom, thus covering $30 \%$ of the total network (OMV Petrom website).

\section{The "Țara lui Andrei” Program (Andrei's Country)}

Not limiting itself to having environmental social responsibility policies targeting its internal activities, OMV Petrom has also created projects involving the communities where it operates and the general public. Starting from 2009, such projects have been consolidated in a platform called "Țara lui Andrei".

The actions that make up this social responsibility platform can be split into two categories:

- $\quad$ Projects undertaken by OMV Petrom itself in partnership with various NGOs;

- $\quad$ Projects funded by OMV Petrom after annual project competitions.

One of the most important projects organized on the "Țara lui Andrei" platform is involved in tree plantings, which take place in an organized manner, with the goal of combating various problems affecting local communities, such as landslides, desertification or blizzards during winter. These actions bring together, as volunteers, company employees and people from the benefiting communities. For example, in 2013 , there were two ecological restoration actions in rural areas, and approximately 3200 kilograms of rubbish and waste have been collected (OMV Petrom 2013 Community Involvement Report).

In 2014, the total budget for all community social responsibility actions organized by OMV Petrom was 3.8 million Euros, the highest among Romanian companies (OMV Petrom 2014 Community Involvement Report).

\subsection{KMG International (Rompetrol)}

Rompetrol is the best known brand of KMG International, and is the name under which this company operates its fuel related activities in Romania, Moldova, Bulgaria, Georgia and France (Rompetrol website).

The company is a founding member of the Global Compact Romania Network, and has thus adopted the principles of social responsibility espoused by the program.

Rompetrol has issued its first report on corporate social responsibility on August $18^{\text {th }} 2015$, covering its activities in the $2013-2014$ interval. The report meets the G4 sustainability reporting standards established by the Global Reporting Initiative (GRI). The next report on CSR came out in 2016. The main goal of KMG is to "develop its activities in full compliance with the environmental regulations of each country where the group operates, applying the general principles of environmental protection by means of resource conservation and sustainability practices" (KMG International 2013-2014 International Sustainability Report).

In order to meet this objective, KMG has developed a strategy based on various areas of interest, all strongly related to the activities and operations of the group. The main directions of action are:

- Ensuring the compliance of activities and operations carried out by the company with national and international provisions on environmental protection;

- Minimizing environmental incidents;

- Minimizing the consumption of natural resources;

- Decreasing the amount of waste that is generated, particularly in the case of dangerous waste products;

- Optimizing operations and technologies for achieving a higher degree of energy efficiency and reducing various polluting emissions, especially those that contribute to the greenhouse effect;

- Improving the certified environment management system (ISO 14001) that is implemented in all the entities that make up the KMG Group;

- $\quad$ The permanent training of staff; 
- Ensuring an excellent communication inside the Group and in its relations with stakeholders.

In 2013, the Petromidia oil refinery successfully completed its transition period for bringing its production installations up to European environmental standards. In the same year, the refinery received a new integrated environmental authorization from the Constanta Environmental Protection Agency, which is valid for 10 years. This authorization recognizes that the production installations of the Petromidia platform operate at the highest performance and environmental protection standards and sets the conditions and parameters that have to be currently met by the refinery (levels of atmospheric emissions, soil and water quality, waste management measures).

Another accomplishment of the Group is the compliance with national and international regulations in the areas of sulfur oxides, nitrogen oxides and particles emissions. During the analyzed period, the company also undertook projects to rehabilitate environmentally degraded areas (Rompetrol website).

Once again in 2014, Rompetrol completed the project titled "Installing a particle emission reduction system at the catalytic cracking installation - Electrostatic precipitator", thus complying with Decision no. 379/05.06.2012 of the Constanta Environmental Protection Agency, which represents an investment with a positive effect on nature.

All the fuels that are sold by Rompetrol Refineries are certified by the Romanian Automobile Registry, and the company has maintained its certifications for management quality, environmental protection and health and safety in 2013 and 2014.

According to the policy of KMG International, the operations of all companies that make up the group must implement the rules of energy efficiency management in their business plans and must evaluate, prioritize and apply technologies and systems aimed at using energy in a more efficient manner. As a result of all these sustained efforts, the company's production has become more energy efficient over the years. A consequence of the constant improvement of processes and activity management elements, as well as of significant investments in new technologies, is the fact that KMG International has successfully aligned itself with existing national and international rules on sulfur and nitrogen oxides atmospheric emissions (Rompetrol website).

Going beyond the social responsibility policies by which KMG International strives to reduce the impact that its activities have on nature, the company has also launched a program through which it finances social responsibility projects that seek to develop communities. The national program "Together for Everyone", launched in 2009, aims to involve local communities in initiating, sustaining and implementing projects in the areas of healthcare and environmental protection (Rompetrol website, "Together for Everyone" project; „Together for Everyone” project website). As of 2015, 1.5 million dollars worth of financing has been offered, which helped support 101 development projects in communities across Romania and the Republic of Moldova. Funds were distributed evenly between healthcare and the environment. The main goals of environmental projects were: ecological restoration actions, preserving and improving environmental conditions at local scale, waste management systems, the rehabilitation and enhancing of degraded lands and other innovative projects with environmental applications.

\subsection{Coca-Cola HBC Romania}

Coca-Cola HBC Romania is the largest consumer goods company in the country and a leader in the field of non-alcoholic beverages, with an annual production volume of approximately 153 million units in 2015 (Coca-Cola website).

Its first CSR report appeared in 2012, and was written following the GRI standards (Global Reporting Initiative). The next report came out in 2015 and analyzed the social responsibility policies for the $2012-$ 2014 interval (Coca-Cola website, Reporting our Progress, 2015).

By means of the environmental component of its social responsibility policy, the company attempts to perform actions that minimize the environmental impact of its activities. An important aspect of this undertaking was the implementation of the ISO 14001 environmental management standard. This certification was achieved in 2004 and has been maintained to this day. The environmental projects of CocaCola HBC Romania follow three directions where the environmental impact of economic activities is most severe: protecting water resources, combating climate change and decreasing energy consumption and, finally, the issues of packaging and waste management.

For each of these three domains there are performance targets and periodic reports on progress achieved in meeting the said targets. 
Marking a step forward from the projects that seek to improve internal efficiency, Coca-Cola HBC Romania has also carried out actions aimed at a wider audience. One example is the "Green Danube" project, in partnership with the International Commission for the Protection of the Danube, which includes both preservation and educational actions in Romania and nine other countries from the Danube's basin. CocaCola HBC Romania is also involved in a partnership with WWF (World Wildlife Fund) for celebrating the "Earth Day" event where the goal is to promote the reduction of energy waste among the general public (Coca-Cola website, Environment).

\subsection{Holcim Romania}

Holcim Romania is one of the most active investors in the national construction industry. It belongs to the LafargeHolcim Group, created after the fusion of Lafarge and Holcim in 2015.

The company owns and operates two cement factories, in Câmpulung and Aleșd, a grinding station in Turda, a network of 14 eco-friendly concrete mixing stations, 3 aggregate stations, 2 special binding agents stations, one cement terminal in Bucharest and another one in Turda (Holcim website).

Due to its specific activities and its size, Holcim has a significant impact on the environment. This impact is recognized and efforts are being made to reduce it, by means of the company's environmental social responsibility policy. Holcim is the second Romanian company to have published a social responsibility report, back in 2005. A series of annual reports followed, until 2011, when the last such report was published. Nowadays, information on the company's social responsibility policy is presented in a special section of its website.

According to its own strategy, "the goal of LafargeHolcim is to create shared value with society by using four key directions of action: climate protection along the entire production chain, the development of innovative products and solutions for improving the energy efficiency of buildings, the promotion of a business model that preserves and optimizes natural resources and the support offered for community development."(Social Responsibility website, Holcim Romania).

The environmental management system of the company was implemented in accordance with the ISO 14001 standard, and, in addition, the system is verified each year by the SGS international certification organism.

The main objectives of Holcim's environmental policy are: reducing atmospheric emissions resulting from the production process, creating low environmental impact products, the use of natural resources in an efficient way and the rehabilitation of dilapidated industrial areas.

As a means of decreasing its atmospheric emissions, Holcim came up with the concept of an "ecological concrete station" (Holcim website). Thus, the company invested in upgrading its production facilities, with elements such as a continuous monitoring system for emissions generated by clinker furnaces, installations for selectively reducing NOx emissions in a non-catalytic method and modern dust filters (which are periodically replaced).

For reaching its objective of creating low impact products, that cause minimal damage to the environment, Holcim is running a program titled "Concrete with composite cements - a durable and energy efficient solution for combating climate change in the constructions sector". The company's production activities have been focused on this type of products, whose carbon footprint is much smaller (Holcim website).

Holcim operates in a very energy-intensive branch and one of the projects that comprise its environmental social responsibility policy involves both energy and resource consumption and waste management. The project is represented by a co-generation plant using a wide range of waste materials, which are first treated and then incinerated, thus being used for energy production.

In addition to internal activities, Holcim has also started several programs aimed at society at large. The most important national project is called "Create your environment", and is an educational program initiated in 2004, in partnership with the Concept Foundation and the Ministry of Education, Research and the Youth (Social Responsibility website, Holcim Romania).

Its goal is to promote civic behavior, which seeks to protect nature, and is implemented among students starting from the $3^{\text {rd }}$ grade up to the $7^{\text {th }}$ grade.

\subsection{Ursus Breweries}

Ursus Breweries is among the largest beer producers in Romania. It belongs to the SABMiller Group, one of the world leaders in this field. In Romania, Ursus Breweries operates three beer factories, along with another 
small scale production facility (Ursus Breweries website).

The first CSR report targeting exclusively the activities carried out in Romania was issued in 2013, and it contained a presentation of the policies applied between 2010 and 2012. For the national level, the use of an international standard (AA1000APS) for verifying and ensuring the report's quality represented a novelty (Ursus Breweries 2010-2012 Sustainable Development Report).Subsequent reports were issued in 2014, 2015 and 2016, each describing the company's activity over the year prior to its release. The last two reports were structured in accordance with the GRI 4 (Global Reporting Initiative) international model, widely seen as one of the most professional models worldwide.

The CSR strategy of Ursus Breweries follows the Prosper Program, which is implemented in the whole SABMiller Group. The environmental elements of this program include: an efficient management of water resources used in the production process, decreasing the carbon footprint and waste production in the entire value chain, reducing carbon emissions from production activities, promoting sustainable packaging and the introduction of energy efficient refrigerators (Ursus Breweries website).

The efficient management of water resources is very important for Ursus Breweries, since water is the most significant raw material for beer production in terms of quantity. In order to improve efficiency and reduce losses, modernization works have been carried out at all production sites. Furthermore, periodic checkups are performed on installations, with the goal of repairing or preventing malfunctions that can lead to water losses. These actions have generated a reduction of water consumption from 353 liters of water for every 100 liters of beer produced in 2013 to 323 liters of water for every 100 liters of beer in 2014 and an average of 305 liters of water used for producing 100 liters of beer in 2015 (Ursus Breweries 2014-2015 Sustainable Development Report).

Following these investments, it was also possible to achieve a higher degree of energy efficiency, reflected in a $3.09 \%$ reduction in terms of electricity consumption between 2014 and 2015 and a $6.84 \%$ reduction in heating energy over the same interval. The company's carbon footprint was decreased by acquiring raw materials from the local markets, which are closer to the production facilities. For example, in $2013,70 \%$ of all barley came from local sources (Ursus Breweries 2013-2014 Sustainable Development Report).

The social responsibility policy of Ursus Breweries is not restricted to attempts at improving its own activities, as the company also strives to solve a number of social problems. Beginning from 2009, Ursus Breweries is a partner of the Recycling Movement national project. This program functions under the aegis of Ministry of the Environment and Sustainable Development and aims to inform and to raise awareness with regards to the topic of recycling. Starting from the first edition, in 2010, the company was also involved in the Let's Do It Romania campaign, which organizes cleaning and ecological rehabilitation actions at national level. As of 2015, more than 1000 employees of Ursus Breweries have participated in such actions (Ursus Breweries website, Social Responsibility).

\section{CONCLUSIONS}

From an environmental perspective, the concept of CSR is becoming more and more important as the environmental impact of economic activities increases. In Romania, after the 1989 regime change, a period of social and economic opening towards international trends and currents followed suit. As social and economic interactions with the outside world grew, the concept of social responsibility began to take hold in Romania as well.

After performing our analysis, we can say that, in Romania, CSR has several defining traits. One of them is its dual structure, consisting of, one the one hand, a set of internal policies and actions that seek to reduce the environmental impact of economic activities, and, on the other, a set of policies through which a company interacts with the external environment and with the community where it exists, and tries to support its development. Corporate Social Responsibility is a very calculated behavior that should serve as the basis for the operations of a company or corporation, a behavior that will naturally lead to long term profits,

\section{REFERENCE LIST}

Cambridge Business English Dictionary (2011). Cambridge University Press. Cambridge

Coca-Cola website. http://www.coca-colahellenic.ro/Home/

Coca-Cola website. Environment section. http://www.coca-colahellenic.ro/Towardssustainabilit/Environment/ 
Coca-Cola website. Reporting our Progress section (2015). http://www.cocacolahellenic.ro/Towardssustainabilit/Reportingourprogress/

CSR Agency website. http://www.thecsragency.ro/

CSR Agency website. Reporting section (2016). http://www.thecsragency.ro/csr-sustainabilityservicers/reporting/

CSR Report website (2015). http://www.csrreport.ro/rapoarte-csr-sustenabilitate/companiile-la-raport.html

Dictionary of the Romanian Language (2nd edition, revised and completed) (1998). Univers Enciclopedic Press. Bucharest

Global Compact Network Romania website. http://www.globalcompactromania.ro/about/

GSK Romania 2013 Corporate Responsibility Report. http://www.csrreport.ro/rapoarte-csrsustenabilitate/raport-de-responsabilitate-corporativa-gsk-romania-2013.html

Holcim Romania 2005 Sustainable Development Report.http://www.csrreport.ro/rapoarte-csrsustenabilitate/raport-dezvoltare-durabila-holcim-romania-2005.html

Holcim website. http://www.holcim.ro/despre-noi.html

KPMG 2013 Survey of Corporate Responsibility Reporting. https://www.kpmg.com/Global/en/IssuesAndlnsights/ArticlesPublications/corporateresponsibility/Documents/kpmg-survey-of-corporate-responsibility-reporting-2013.pdf

KMG International 2013-2014 International Sustainability Report (2015). http://www.rompetrol.com/sites/default/files/report complete simulated en redux.pdf

Mănoiu V.-M., Gâdiuţă A.V. (2016). Social Responsibility and its Environmental Component: Origins, Evolution and Organizations Involved. IJASOS-International E-Journal of Advances in Social Sciences, 2 (6), 631-640. DOI: 10.18769/ijasos.280338 Available at http://ijasos.ocerintjournals.org/ijasos/issue/26675/280338

OMV Petrom 2011-2014 Sustainability Reports. https://www.omvpetrom.com/portal/01/petromcom/petromcom/home/Sustainability/Raport de sustena bilitate

OMV Petrom 2013 Community Involvement Report (2014). http://www.omvpetrom.com/portal/01/petromcom/petromcom/home/Sustainability/Raport de sustenab litate/Rapoarte de implicare in comunitate/Raport de implicare in comunitate 2013

OMV Petrom 2013 Sustainability Report (2014). https://www.omvpetrom.com/portal/01/petromcom/petromcom/home/Sustainability/Raport de sustena bilitate\#2013

OMV Petrom 2014 Community Involvement Report (2015). http://www.omvpetrom.com/portal/01/petromcom/petromcom/home/Sustainability/Raport de sustenab ilitate/Rapoarte de implicare in comunitate/community-involvement-report-2014

OMV Petrom website.https://www.omvpetrom.com/portal/01/petromcom/header/Home

Oprea L. (2005). Responsabilitatea Socială Corporatistă. Tritonic Publishing Press. Bucureşti

Orange Romania 2003 Social Responsibility Report. Available online at: https://www.orange.ro/about/2003 raport csr.pdf

Orange Romania 2006 Corporate Social ResponsibilityReport. Available online at: http://www.responsabilitatesociala.ro/images/stories/files/Raport CSR Orange 2006.pdf

Rompetrol website. http://www.rompetrol.com/ro

Rompetrol website. Together for Everyone project section. http://www.rompetrol.ro/csr/impreuna-pentrufiecare

Social Responsibility website. http://www.responsabilitatesociala.ro/

Social Responsibility website. Holcim Romania section. http://www.responsabilitatesociala.ro/companii/holcim-romania.html 
Together for Everyone project website. http://www.impreunapentrufiecare.ro/

Ursus Breweries 2010-2012 Sustainable Development Report. http://www.csrreport.ro/rapoarte-csrsustenabilitate/raport-dezvoltare-durabila-ursus-breweries-2010-2012.html

Ursus Breweries 2013-2014 Sustainable Development Report. http://ursus-breweries.ro/uploads/RaportDezvoltare-Durabila-2014-engleza.pdf

Ursus Breweries 2014-2015 Sustainable Development Report. http://ursus-breweries.ro/uploads/RaportDezvoltare-Durabila-2015-engleza.pdf

Ursus Breweries site. http://ursus-breweries.ro/http://ursus-breweries.ro/sabmiller-in-romania/

Ursus Breweries website. Social Responsibility section. http://ursus-

breweries.ro/responsabilitate/responsabilitate-sociala/ 